\title{
老朽トンネルにおけるクラック診断 システムの開発
}

\section{安田 亨* ・谷口親平 $* *$ ・亀和田俊一 $* * *$ \\ - 岡野吾—****}

\begin{abstract}
本報告は, トンネル坑壁の連続画像記録解析装置を基本とするクラック診断システム により, 老朽トンネルの概略の変状傾向を把握し, クラックの発生原因を推定したもの である. 本システムの特徴は，1）迅速で, 客観的な調查ができる，2）画像記録・処理・ 分析にはパソコンを用いる等である. システムを適用した結果, クラックに着目し成分 を分析することにより，ある程度の原因推定ができることがわかった．
\end{abstract}

Keywords : crack evaluation system, continuous image database

\section{1.はじめに}

平成 2 年 2 月に起きた国道 127 号線小山野トンネルの 崩落事故を契機として，老朽トンネルの安全を確認する 必要性が高まり，現在各地において緊急点検が実施され ている1．この点検は主としてクラックや漏水などの覆 工の変状を中心に行われているが，調査現場では，狭く 危険な作業環境の中で熟練調査員が煩雑な調査を手作業 によって行っているのが実態である.このような方法で は,

(1) 調査員の熟練度によるところが大きく正確さや客 観性に久ける,

(2) かなりの時間を要する，

(3) 定量的に評価することが難しい,

(4) 現地で即時的に判断できない,

(5) 定期点検で定量的に追跡することが難しい,

等の点で問題がある。また，老朽トンネルの調査法は各 機関から提案されており, 維持管理のフロー, 具体的な 調査手法, 判定基準等が報告されている2)-7).この中に は，調查から対策工の選定までをマニュアル化した研 究5)や，トンネルの健全度や対策工をエキスパートシス テムを用いて判定した研究 ${ }^{51,71}$ があり, 変状調查をシス テム化しようとする気運が高まっている.

しかしながら，以上の研究においても，調査自体をシ ステム化するには至っておらず，先に述べた調査時の問 題点は未解決のままとり残されている.

そこで, 筆者らはこの問題点を解決するための 1 手法 として, トンネル坑壁の連続画像記録解析装置を基本と

*正会員 パシフィックコンサルタンツ（株）西日本事業 本部第一技術部（テ532 大阪市淀川区西中島 4-3-24）

**正会員 パシフィックコンサルタンツ（株）西日本事業 本部第一技術部

***正会員（株）レアックス代表取締役

**** (株) レアックス業務部
するクラック診断システムを開発した。このシステムは 概略の变状傾向を迅速, 客観的に把握することを目的亡 しており, クラック, 漏水, 目地異常等の坑壁の画像記 録を取り込んだのち, 比較的容易に変状傾向を知ること のできるクラックに着目し，クラック発生原因を推定し ようとするものである.

このシステムは, 次に示す点を開発目標としている.

(1) 短期間に全体の変状傾向を把握し, 客観的なデー 夕を提供する.

(2) 画像記録を定量的に扱う方式とし，パソコンに よって画像処理・成分分析を行う.

(3) 問題箇所の判定, 変状原因の究明, 健全度の判定, 対策工の検討等を熟練者の知識を付加してデータ ベースを蓄積し，エキスパートシステムを構築す る。

これらの目標のうち，現段階では(2)まで実用化してい る.

本報告では，このシステムによってクラックを記録し 変状原因の推定を行うまでの一連の流れを, 実施例を用 いて紹介する.

\section{2. システムの概要}

本システムの概要を図一1のフローチャートに示す.

\section{（1）連続画像記録方法}

トンネル坑壁の画像記録装置として, CIMEDAS (Continuous IMagE DAtabase System) を使用した. 本システムは, ボーリングコア等の長尺の物体を画像 フィルム化するために開発した装置で, 一定幅の連続画 像をスキャニングによってデジタル的に取り込み，最終 的に光ディスク上に画像データベースを構築することが できる，本装置をトンネル坑壁調査に応用するため，専 用のカメラヘッドおよび坑壁照明装置を制作し，全体を 車載してトンネル坑内を走行するものとした．装置の構 
開発目標とするシステム權成

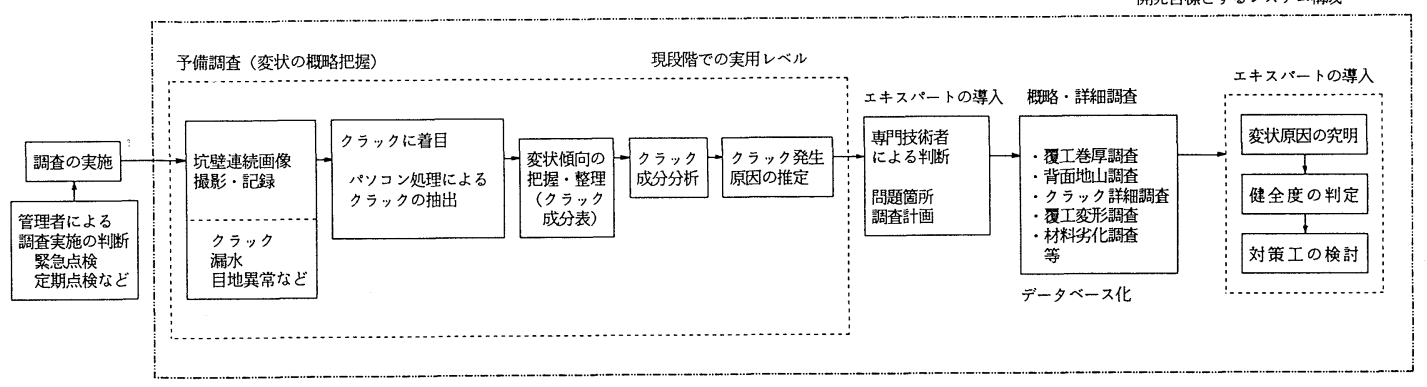

図一1 システム概要フローチャート

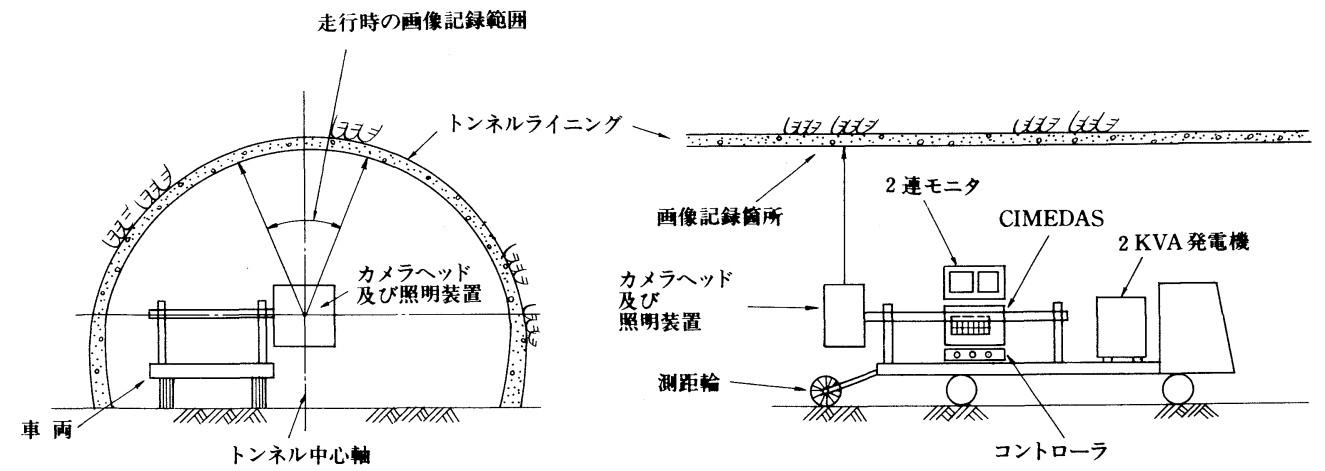

図一2 坑壁画像記録概念図

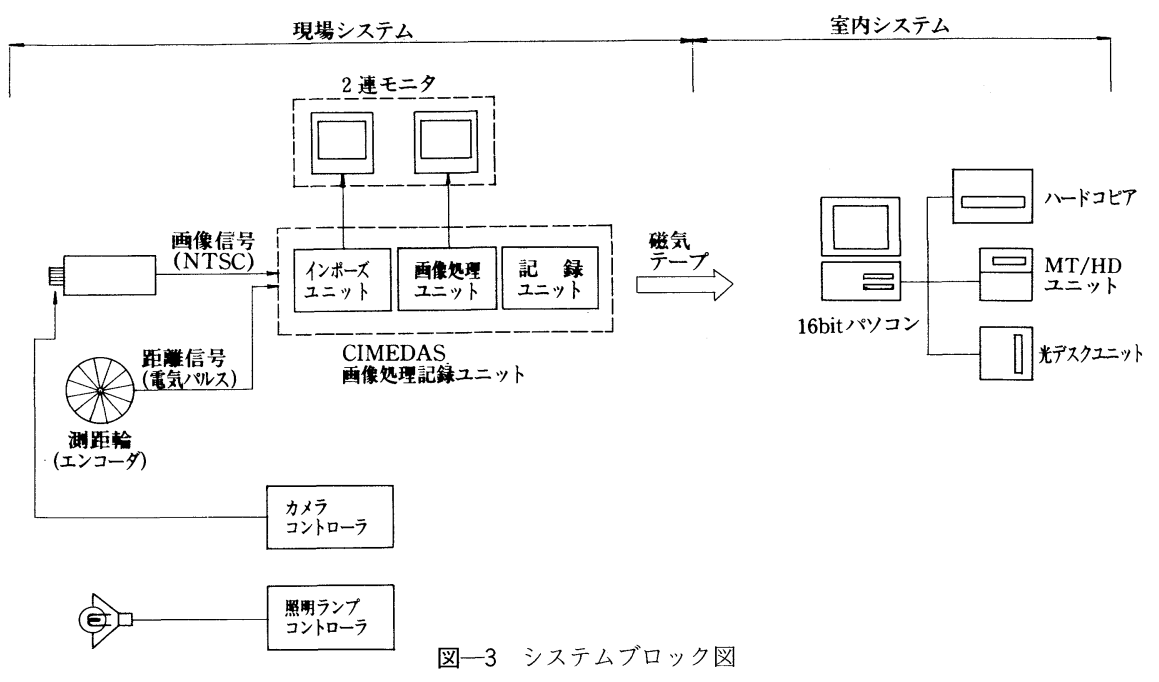

成を図一2に示す。また，記録システムのブロック図を 図一3に示す.

本装置によってトンネル坑壁を画像記録する場合には

(1) カメラヘッドがトンネル中心軸に位置するように 車両上に固定する.

(2) 車雨をトンネル軸に沿って走行させ, 一定軸の坑 壁画像を連続的に取り込む.

(3) 画像処理装置によってリアルタイムにデジタル変
換し，磁気テープに記録する.

(4) 以上の作業をカメラヘッドの方向を変化させなが ら繰り返し，坑壁全体の画像（必要に応じて路面 も）を記録する。

(5) 室内処理装置によって光ディスク上に画像データ ベースを作成し，これを基に坑壁全体のハードコ ピーを出力する.

以上の作業は, 画像精度にもよるが $1 \sim 2 \mathrm{~km} / \mathrm{h}$ 程度 
表一1 クラックの定量化項目

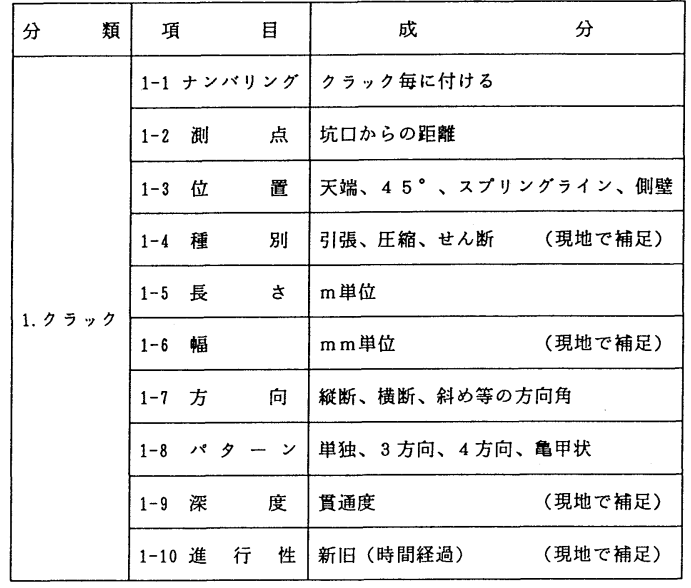

の走行速度で行うことが可能で，またカメラヘッドを車 両に対してオフセットして取り付ければ，片側車線規制 の状態で作業することができる。

\section{（2）クラックの定量化項目}

老朽化の進んだトンネルにはクラックが発生している ことが一般的である。

この原因として, 材料劣化, 施工上の不備, 外力の作 用などが挙げられる.

一般に, 不良地山, 断層部, 偏地形, 低土被りなどの 条件下では，トンネルの覆工は外力を受けることになり 断面変形, 大規模なクラックの発生, 目地異常などの変 状がある程度の区間にわたって生じることが多い。地山 情報が残っていない古いトンネルでは, 上記の変状原因 を探る上で，まずクラックに着目し，クラックの方向， パターン, 種別, 長さ, 密度などを整理することは, 有 力な手がかりとなる. また, クラックの成分を定量的に 評価しておくことは，時間的経過に伴う变状の進行を調 查する場合などに有効である.

以上の点を踏まえ, 表一1 に示す定量化項目をクラッ ク情報として位置付ける.なお, 画像では十分に読み取 ることのできない項目について（例えば，表一1の種別， 深度, 進行性) は, 現地にて熟練者が判断し, デー夕を 補足する.

\section{（3）クラックの画像処理方法}

画像は，任意幅に対して $256 \mathrm{dot} /$ line の精度で連続的 に取り込まれることになり, 分解能は一回の取り込み幅 を画角 $30^{\circ}$ とすれば $0.12^{\circ} / \operatorname{dot}$ となる. 検出能力は分解 能をかなり上回るので; 肉眼でも見えるものについては ほぼ画像化が可能である. 画像の深みは, 各画像当たり RGB 各 8 bit（256 階調）あり, ほぼ自然色での表示が 可能である.この場合の情報容量は $100 \mathrm{~m}$ あたり 20-40 $\mathrm{MB}$ 程度を必要亡する.

画像化の結果から，クラックをパソコン上で対話型式
により読み取り，位置・長さ・方向等のデータを自動検 出する.なお，画像のみでは読み取れないデータについ ては，現地で補い手入力する.

\section{(4) 成分分析}

画像処理および現地での補足により得られたクラック 成分を，パソコンにより成分分析する.この分析により 変状の傾向を把握し, クラックの発生原因を概称推定す る. この資料を専門技術者に提供し, 問題箇所, 調査計 画等を判断する流れとなる.

具体的な方法は，成分表のデータを用いて次の項目等 に関するグラフを作成し，傾向を分析するものである.

(1) 連続性の明瞭な長いクラックの発生位置

(2) 縦断方向クラックの卓越している箘所

(3) クラックの断面的な発生位置（特に縦断方向）

(4) 長さとクラック幅の関係

(5) クラック種類とクラックパターンの関係

(6) クラック密度の高い箇所

(7) 新しいクラックの発生箇所等

\section{3. 実 施 例}

図一4 は，本システムを用いてトンネル上半部の連続 画像をパソコン処理して作成したクラック全体展開図で ある. 本トンネルは昭和 17 年に鉄道トンネルとして築 造されたが (築後 49 年), 廃線後現在まで道路卜ンネル として供用している. 今後も道路トンネルとして供用し 続けることの可否を検討するという目的のため, 調査を 行った.

\section{（1）変状傾向}

図一 4 に示すように, 特徵的なクラックは両坑口部に 多く発生している. 中間部については比較的クラックは 少なく, 連続的な縦断方向クラックや集中的に発生して いる横断方向クラックがないため図示は省略した.

起点側の坑口部は, クラック幅が小さいものの比較的 連続性があって数が多く, 縦断方向が卓越している.こ の区間は, 覆工コンクリートの内側に吹付けコンクリー トが施工されており, 先のクラックは, 吹付けコンクリー トに発生しているものである.

終点側はNO.250〜300 (m) の間に起点側から見て 左から右へ斜交する方向に, 連続性が非常に顕著なク ラックが発生している.

クラック発生は様々な原因が複合されているために, 引張り，せん断などのクラックの種別を断定することは 難しいが, 現地での目視によりこの斜め方向クラックは せん断的傾向が強いと判断した。

また，終点側の左肩部には，比較的連続性が明瞭な縦 断方向クラックが見受けられること等が特徴として挙げ られる。

図一 5 は，図一 4 に丸印で示した箇所をズーミングし 


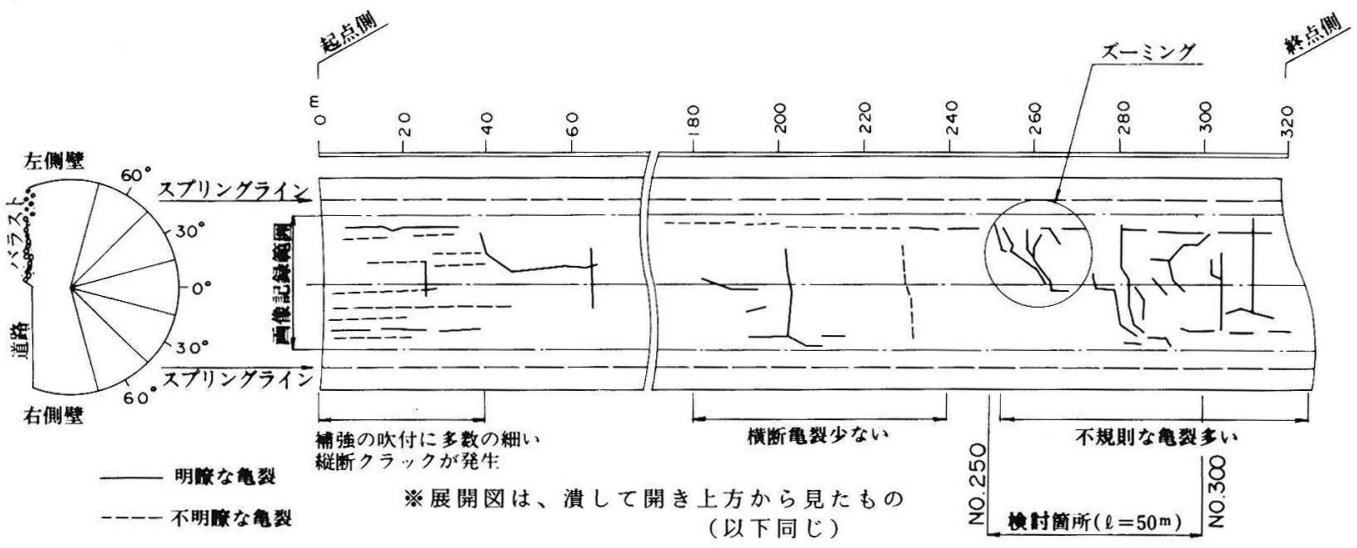

図一4 クラック全体展開図

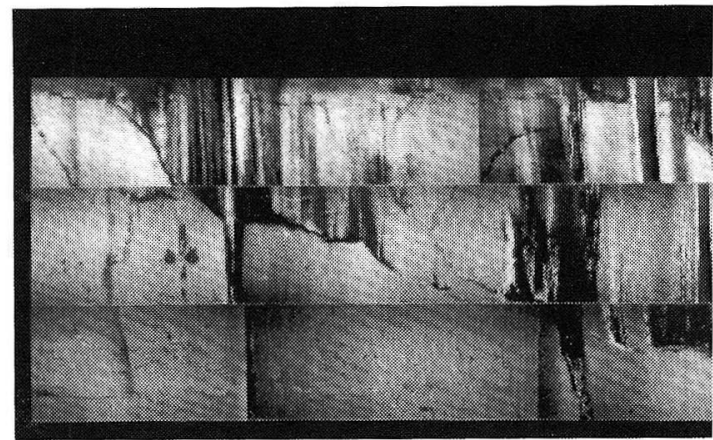

図一5 ズーミングした画像記録

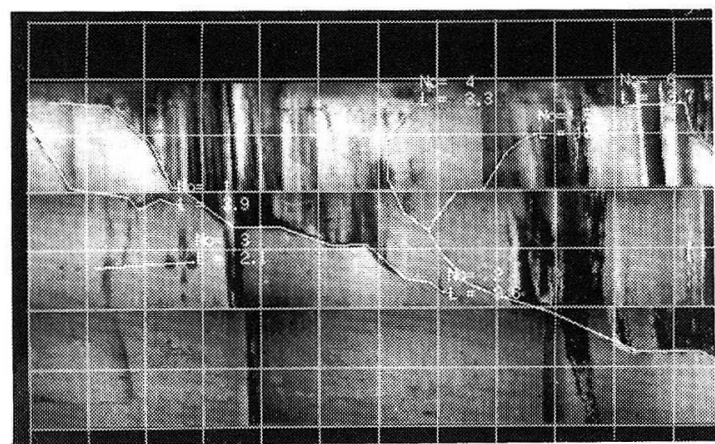

図一 6 処理後のクラック展開図

\section{た画像記録である.}

図一6は，図一5の画像記録をパソコン上で対話式に より抽出したクラック展開図である. 図一6の格子は画 像に落とした座標軸であり，実線がマウスによるプロッ トで作成したクラックである.

\section{（2）クラック発生原因の推定}

先に述べた変状傾向を整理すると, 両坑口部がクラッ ク発生原因推定の検討対象として考えられる.しかし， 起点側は，内巻の吹付けコンクリートのクラックである

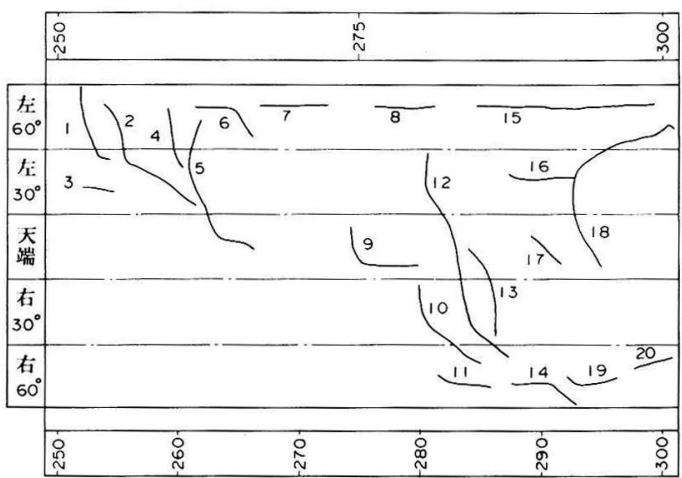

図一7 クラックマップ

こと, 覆エコンクリートの変状は不明であること等の特 殊性から，本システムによる表面の情報のみでは検討が 不十分であるため，終点側のクラックを例にとり，以下 に推定の手順を紹介する.

検討対象とした区間は図一4に示すようにNO.250 $300(\mathrm{~m})$ である. 図一7は本区間のクラックのうち， 目地切れ, ヘアークラックなどを除去して作成したク ラックマップで, クラックNO. を併記してある.これ をもとに表一1の定量化項目にしたがって作成したク ラック成分表が，表一2である．このクラック成分を，

2.（4）に示した観点から分析していく.

本検討箇所でのクラック成分分析図の 1 例を図一8に 示す. 同図は斜交クラック（図一7に示す NO.2, 5 , 10 なよ゙）の発生原因を推定するために，クラック発生 位置, クラック方向, クラック種類, 長さの関係を図示 したものである.これによれば右方向 (30-50) に長い せん断クラックが卓越していること，また終点側に上記 のせん断クラックに直交する方向 $\left(-25^{\circ}\right)$ に引張クラッ クが発生していることが分かる。 また左側壁部に縦断方 向クラックが連続して発生しており, 右側壁部にはク ラック NO. 10, 12 などの斜交クラックが終了した位置 
表一2 クラック成分表

\begin{tabular}{|c|c|c|c|c|c|c|c|c|c|c|}
\hline & $\begin{array}{l}\text { 始点 } \\
\text { (測点) }\end{array}$ & $\begin{array}{l}\text { 終点 } \\
\text { (測点) }\end{array}$ & 1234 & 璉別 & $\begin{array}{r}\text { 長さ } \\
\text { (m) }\end{array}$ & $\begin{array}{l}\text { 幅 } \\
(\mathrm{mm})\end{array}$ & $\begin{array}{c}\text { 方向 } \\
0^{\circ}\end{array}$ & $\begin{array}{l}\text { バタ } \\
\text {-ン }\end{array}$ & 深度 & 進行中 \\
\hline 1 & & & $\mu$ & 3 & 3.9 & 3.0 & 45 & 1 & 1 & \\
\hline 2 & 253.8 & 62.0 & 4 & 3 & 9.6 & 3.0 & 25 & 2 & 1 & \\
\hline 3 & 252.0 & 255.3 & & 1 & 2.1 & 2.0 & 0 & 1 & 2 & \\
\hline 4 & 259.0. & .0 & & 3 & 3.3 & 0.5 & 55 & 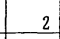 & 1 & \\
\hline 5 & 62.8 & 6.5 & 1 & 3 & 10.1 & 1.0 & 35 & 2 & 1 & . \\
\hline 6 & 261.0 & 266.3 & & 3 & 3.7 & 2.0 & 50 & 2 & 1 & 1 \\
\hline 7 & 266.5 & 273.0 & & 3 & 6.3 & 2.0 & & 1 & 1 & 1 \\
\hline 8 & 275.5 & .0 & & 3 & 6.5 & 2.0 & 0 & 1 & 1 & 1 \\
\hline 9 & 274.3 & 280.0 & & 3 & 5.5 & 1.0 & 45 & 1 & 1 & 1 \\
\hline 10 & 280.0 & 286.0 & & 3 & 8.8 & 2.0 & 35 & 1 & 1 & \\
\hline 11 & 281.5 & 285.5 & & 3 & 4.0 & 2.0 & 5 & 1 & 1 & 1 \\
\hline 12 & 280.8 & 287.5 & & 3 & 11.6 & 2.0 & 50 & 2 & 1 & 1 \\
\hline 13 & 283.5 & 286 & & 3 & 7.8 & 1.0 & 30 & 2 & 1 & 1 \\
\hline 14 & 287.3 & 5 & & 3 & 6.7 & 2.0 & 10 & 1 & 1 & 1 \\
\hline 15 & 284.0 & 297.5 & & 3 & 13.8 & 2.0 & - & 1 & 1 & 1 \\
\hline 16 & 287.5 & 292.5 & , & 1 & 5.0 & 3.0 & -5 & 2 & 2 & 1 \\
\hline 17 & & & & 2 & 4. 5 & 0.5 & 30 & 1 & 2 & 1 \\
\hline 18 & 295.5 & 300.0 & & 1 & 15.2 & 2.0 & -25 & 2 & 2 & 1 \\
\hline 19 & 292.0 & 7.0 & & 3 & 4.8 & 2.0 & -5 & 1 & . & 1 \\
\hline & & 300.0 & & 3 & 2.0 & 2.0 & -5 & 1 & 1 & \\
\hline
\end{tabular}

\begin{tabular}{|c|c|c|c|}
\hline 凡例: & 位置 1 -左 $60^{\circ}$ & 種別 1-引張 & ラックの方向 $\left(^{\circ}\right)$ \\
\hline & 2 -左 $30^{\circ}$ & 2-圧縮 & トンネル軸線に対して起 \\
\hline & 3-天端 & 3-せん断 & から見て \\
\hline & 4 -右 $30^{\circ}$ & & 左方向が(-) \\
\hline & 5 -右 $60^{\circ}$ & & 右方向が(+) \\
\hline & 深度 1-貫通 & 進行性 1-旧 & パターン 1-単独 \\
\hline & 2-非貫通 & 2-新 & 2-3方向 \\
\hline & & & 3-4万向 \\
\hline & & & 4-毫甲状 \\
\hline
\end{tabular}

から, 縦断方向クラックが発生していることなどが分か る.

以上から, 斜交クラックについては, クラックの規模 (長さ, 幅) から考えて, 外力を受けて発生したものと 考えられ, 方向が一様であること等からトンネル軸に対 して斜め方向にせん断されたことがクラックの発生原因 であると推定した。

なお, 終点側坑口部の地形は図一 9 に示すように偏地 形となっており，トンネルは斜面に斜交して取り付けら れている.また斜面上の植生に変状が見受けられ斜面ク リープの可能性があること, および斜交クラックの方向 が斜面にほぼ平行していることなども, 原因を推定する 上で参考にした。

\section{4. おわりに}

\section{（1）成果}

本報告は, クラックの成分に着目し，トンネル坑壁の 連続画像記録解析装置を用いてクラックの診断システム を開発したものである. システムとしてはまだ不十分で

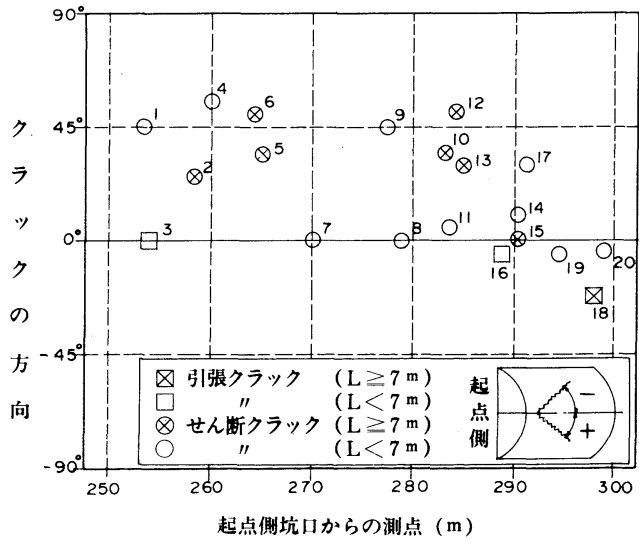

図一8 クラックの成分分析図の 1 例

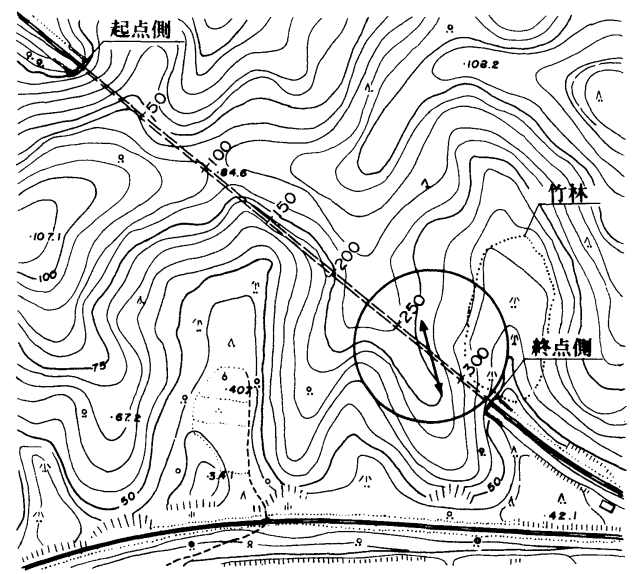

図一9 終点側坑口付近平面図

はあるが，現段階において次の成果が得られた.

(1) 本システムは現地作業の問題点を解決することを 目的の一つに挙げているが, 迅速性, 客観性の向 上という点で一応の評価ができた。

(2) 本システムは予備調查として位置付けているた め, クラックの発生原因を明確に究明するには力 量不足である. しかし, クラックに着目し成分を 分析することにより，ある程度の原因推定はでき たと考えている.

(3) 本画像記録装置は, クラック位置・長さ・方向な ビを客観的かつ機械的に取り込むことができるた め，パソコン処理に馴染み易い点で評価できた.

\section{（2）今後の課題}

今後は以下の課題に取り組んでいきたいと考えてい る.

(1) 坑壁記録技術の改良

現在のシステムを使用して, 延長 $500 \mathrm{~m}$ 程度のトン ネルの坑壁画像記録は, 片側車線規制の状態で, 5 6 時間程度で完了することができる. しかし，トンネルの 
交通量によっては長時間の車線規制が困難である場合も あるので，現場での作業性を極力向上させることが必要 である.このため, 同時に多方向の撮影記録を可能とし， 往復 1 回程度の車両走行によって作業が完了するよう改 良する計画である，さらに，維持管理の目的で画像記録 を行うためには，同一地点の詳細画像を繰り返し記録す るような工夫も必要であると考える。

(2) 画像処理技術の改良

変状の迅速な判断のためには，現場でのハードコピー の出力が必要である.このため現場での合成処理, 連続 したハードコピーの出力装置などの追加が必要である.

(3) エキスパートシステムの構築

トンネルの健全度を診断するための有効な他の定量化 項目として, 材料劣化, 覆工巻厚, 覆工背面の空洞・岩 質・ゆるみ状況, 漏水, 目地のずれ, 側溝の変状および 地形・地質状況, 地層の走行傾斜, 断層位置などが考え られる。

特に覆工背面は重要で, レーダーを用いる方法やボー リングを行ってボアホールカメラ (BIPS : Borehole Image Processing System $)^{8)}$ を用いる方法などでク ラックデータを補完することは有効となろう.

本システムの実用レベルは, 予備調查の段階までであ る. 今後は開発目標に述べたように，上記の項目や，専
門技術者の判断，実施例などを組入れて，老朽トンネル の健全度を診断し，適切な対策工が示唆できるエキス パートシステムに発展させていく計画である。

最後に, 本研究の実施にあたって名古屋大学川本朓万 教授の御指導を頂いたことを記して謝意を表します。

\section{参 考 文 献}

1) 猪熊 明: 道路トンネルの緊急点検と今後の維持管理, トンネルと地下, Vol.21. 10, pp. 35〜40, 1990.10.

2）日本道路協会：道路震災対策便覧，1988.2.

3）日本道路協会：トンネル技術基準（構造編），pp.265～ $272,1987$.

4）国鉄・道路公団他：トンネルの保守・維持管理シリーズ (1)〜(9), トンネルと地下, Vol. 15.

5）鉄道総合技術研究所：トンネル補強・補修マニュアル, 1990.

6）（社）日本トンネル技術協会：山岳トンネルの老朽対策に 関する調查研究（その2）報告書（日本道路公団委託）, 1991.2.

7）柴田・松本・安藤：「水力発電所導水路トンネル健全度診 断・改修工法選定システム」の開発，電力土木 No. 232, pp. 14 24, 1991. 5 .

8）谷口・亀和田・米田：既設トンネル周辺岩盤の調查手法 と設計への応用, 土木学会論文集 $\mathbb{N}$, No. 409, pp.139 $144,1989.9$.

(1991.1.21 受付)

\section{DEVELOPMENT OF A CRACK EVALUATION SYSTEM FOR SUPERANNUATED TUNNELS}

Toru YASUDA, Sinpei TANIGUCHI, Shunichi KAMEWADA and Goichi OKANO

In this report the crack evaluation system for analyzing the condition of superannuated tunnels is discussed. This system is based on analysis of continuous image recording of tunnel walls. The system is characterized as follows :

1) It enables quick and objective investigation ;

2) Personal computer are adequate for the image recording, processing, and analysis ;

3) It aims to provide for the structuring of an expert system for finding causes of deformation.

In applications of the system we found that analysis of crack elements was useful in finding the causes of deformation. 